\title{
The Mother, the Daughter, and the Holy Horse: A Trilogy · Judy Ruiz
}

\author{
Women Know Nothing
}

The worst feeling of lost I ever had was when I was eighteen. I'd left home, I think. Maybe not. Those times were so intensely sad that I lose track. One night, I drove around in a '55 Chevy all evening, knowing that the man who owned the car would want something in return for letting me drive it, not to go all the way, as we called it back then, but to do some kissing, maybe some petting. So I drove and drove and it never entered my mind to just abandon the car. I drank 3.2 beer and drove some more.

Finally, around midnight, I drove the car back to the owner's house. $\mathrm{He}$ was waiting for me on his porch. He came out to the car and got in and wanted to kiss me and he had a harelip, with a voice that seemed to come from a well inside his head. All I can remember is that I didn't want to kiss him, but I felt I owed him because he had let me drive his car around all night. Now I can't remember if I kissed him, but I think I did.

Then I walked to a friend's apartment in hopes of getting some sleep. He let me in and I asked if I could sleep there and he said sure. I had awakened him, but he went right back to bed, without turning any lights on. I took off my shoes and got into his bed in my clothes. We slept.

He woke me up kissing me and touching my breasts, and then he was on top of me and he didn't pull my panties off. He just pulled the crotch part over to one side and went inside me. It was over with in about a blink. I got up and asked him if I could wash my clothes out in the sink and stay there until they were dry enough to wear. He said sure and gave me a shirt of his to wear. I washed my skirt and blouse and hung them by the space heater to dry. It was cold that autumn. Then his parents came over.

I was sitting on a chair by the heater with my legs hanging out. He talked to his parents. They wanted to know who I was and he told them, "No one. She needed a place to sleep."

The author thanks Terry Compton for permission to use this title, and for writing the poem "Women Know Nothing," which inspired and informed the writing of this essay. 
That was the worst feeling of lost I ever had. It's been thirty years since that night, but that feeling, the edge of it, or the curve of it, or the shade or space or dark of it, is still with me. Not that I think of it every day. But that it ever happened so that I would ever have to think of it, even now, is my empty house, or at least a part of it.

That a woman should be so tired at the age of eighteen that a man could enter her, that she would need sleep, just a bed, a place, a shelter, so desperately that she could feel him pull at her underwear and not have the idea to scream or move or say no, that she would help herself to become who she was to him that night-no one-that these things happened is beyond God, this earth, or ever.

When you get out of prison, my sweet son, I will go with you and we will find your father, and you will see his face. And perhaps, some day, you will forgive me all of this - my passion and his. This is how you were conceived: in a sudden heat.

It sounds too schmaltzy. I know. Forgive me that too. And forgive me all the other miserable fucking things I ever did because I couldn't love or do a thing softer than I did once I found fire. These requests for forgiveness are hereby entered into the world of people and the realm of tell me doctor, if she's sane enough to strike a proper bargain, how can we keep her in the confines of her skin? I was going to write "the world of people and the realm of God, this world, or ever." I was going to write "the realm of people and the world of God." I was going to write the word bastard and get it over with. But he was my baby. Mine.

This is where it always happens, this room where the light pours in and the walls are white. This is where the alpha and omega, the yin and yang, the past and present, the withdrawals - all of it happens right here and the room rears its ugly head and says who cares. Recipes get invented here, lists made, addresses entered and deleted. The cats can't come in anymore. They eat the plants and bathe on the keyboard and chew the corners of the disc covers and mainly do not understand that this is where it always happens and if I were young, I would birth a child in this room and gnaw the cord with my teeth and open the windows and let the elements freeze us in those first few hours, me, drunk from the perfect rush of birth, the baby nursing the death away. 
Pretend there's some music in the background, music from the part of the movie when a famous literary figure from long ago time-travels into the present only to find herself at some local bar which is alive with purple faces and wheezing laughter. Camera pan to a person who leans into our literary figure's face, a person who says, "But to put it into perspective, Virginia, this room-of-one's-own thing, Virginia, or may we just call you Virgin, for short, but not for long." Sweep shot of laughter all around and a little bit of back-slapping. Close up of Virginia's face, how the corners of her mouth do not make a move in any direction. Close up of the inside of her brain, the left temporal region, where a sentence is just beginning to form. Watch carefully as the words appear on the screen. Follow along, if you will. The dot above the word, like in those old sing-along film clips, will tell you exactly where we are.

What do they make those dots from? Okay. Imagine that there is a darkness that is also dense. It presses in and in forever. In the exact center of the dark there is a perfect circle of light. It is about the size of this: 0 . No matter how dense or dark the pressing-in gets, the circle stays the same. Then one day it becomes a dot above a word. No one knows exactly how this happens. Anyhow, follow the dancing dot:

Some of life is inenarrable; however, there is language, and an organ that sits as a ceiling-the brain. Fantasmagorical in its reaches and realms, and physically an organ that is so closed in its nature that it convolutes into itself, the brain tucks into its folds tiny pictures until we, as human beings, are walking photo albums of ourselves-ourselves with others, ourselves alone. One interesting thing about these photographs, these brain ones, is that the "ourself" part is missing, just as gone as if we had taken scissors to the real photographs on the mantle at home and had carefully carved our faces away. The eye of the beholder is an odd eye. It goes to the behelden in the album of the mind. And the camera, which is also the eye of the beholder, but a different eye, an eye with ears and mouth and nose and skin and language, does not lie.

You have made for me this evening, ladies and gentlemen, a picture that may not be pressing in at me at all times, but one, nevertheless, that I shall hold dear from this moment forward, as 
I shall also revere your words to me spoken here in this public establishment. I will show this picture to the world and say, "This is something I want you all to see."

I lost my virginity before I was two. I don't remember much about that one-his penis floating in the water in the bathtub and me being taken into the warm water, how it was different than the pink bag that hung on the door under my mother's robe.

I suppose the other events between then and when I was sixteen and went out in deliberation to "do it" need to be mentioned, not so that anyone will say poor baby, but so what I'm talking about here will have a frame.

There were the usual laps with bulges for a little girl to sit on, there was the cousin in the root cellar, there was the uncle and a summer of dry-fucking, the orthodontist and his hard-on leaning into my shoulder, a lover's kiss from the drunken father in the hallway, and there's just not time for all the list. What there is time for is to say I liked it, I loved it, I craved it. I sat in group therapies later while we all showed our scars, and I never said, "Well, part of the deal here is that I liked it. It always scared the hell out of me and made me feel numb and on fire at the same time."

Maybe there was something about my face. Maybe it was my eyes. Maybe all it took was a glance at me and a person could tell I was so far away already that all it took to go the distance was a little time, a little space, a little privacy. Maybe my eyes said, "Go ahead. I will tell my mother. But she will not believe me. She will tell others not to believe me. She has done this before."

I'd like to yank them all up out of their sleep, even the dead ones, and bring their immortal souls right up to my face and say, "There. I went on and never lost my mind. Not even when my mother told me, when I was forty and she was sixty, how relieved she had been when I, at nineteen, became pregnant for the first time, how she had held her breath wondering if the infection I had when I was little would render me sterile, telling me this over mashed potatoes and gravy in the cafeteria of the hospital where my father lay two days post-operative, having had his testicles removed to ease some of the pain caused by his cancerous tumors, the tumors that fed on testosterone. I was in the hospital with a venereal disease before I was two, so what you did with me was some small fucking potatoes, and I don't even remember all of it, so kiss my perfect ass in your dreams, pal." Then 
I'd let go of them, and they'd all fall, forever and permanently, into the abyss of profound spirituality. They would turn into tiny round circles of light. They could become dancing dots. They could keep track of this:

Tell everyone that I know nothing. Tell them I learned how. Tell them I told.

\section{Remember My Horse}

My friend and I sit attentive in a graduate level creative writing workshop. We are wearing lapel buttons. Her button has these words on it: Come near me and I'll kill you. Mine reads: Just one of the boys.

When class is over, we'll go to a local restaurant, drink hot chocolate, and make lists on napkins - the names of all the people whose hats we'd like to shoot off. We know our anger is impotent, and we know the only revenge worth having is to outlive and outwrite everybody. Our motto is, "Who are these people, and why are they trying to kill us?"

This anger feeling is some strange thing that blasts through me like the suddenness of all the fierce glare of winter light, blinding light, all the blinding cold light. No. It's ice. It's hot ice and it covers the planet and it's a million miles thick. Wait. It's a hammer and I'm hitting myself between the eyes. My aim is true. I hit and it lands hard, not like in those dreams where I hit as hard as I can, and the impact of my blow is less than being touched by a feather, the recipient of my rage standing blank in the dream, as blank as I have stood in the reality.

The first time I felt my own anger, I thought I was dying. That's how serious the reaction in my body was. It was November, 1983. I was almost forty. And I wouldn't remember the date so clearly, except I was in a treatment center when it happened. And it wouldn't have happened if I just could have managed to stay drunk and disorderly, or swacked out on Xanex, for a little while longer. I mean, if I could have just drank and drugged a couple more weeks, I could have been all the way dead, and not merely wandering around in hospital garb feeling the first feeling I can 
remember having felt in my life, the first feeling other than depression, which is not a feeling at all, but an absence of feeling.

Because I thought I was having a heart attack or something, I sought out one of the nurses who reassured me that I wasn't dying and went on to explain what was happening in me: all the depressants (alcohol and drugs) I had ingested during the past twenty-seven years had depressed my nervous system so that my feelings had not surfaced in all those years. She told me I was angry, and that I could expect other surprises in my body as I detoxified. At that time, I thought, "Sure. Whatever." But I didn't know what I was angry with, or why I felt it so hard that it almost knocked me down in the hallway.

Back in the sixties and seventies, a person could attend anger workshopsmaybe they still exist today, I don't know. But back then, you brought a tennis racket to workshop. The cushions were provided. The workshop leader talked with you until you got in touch-that's what it was called, in touch-with your anger. Then you stood, feet apart, brought the racket up over your head, and began to beat on a cushion. I have seen folks ruin tennis rackets this way, beating until all that was left was the handle part. The cushion represented anyone or anything you were angry at or with, from Mom to God to driving in rush-hour traffic.

Another tactic for the release of anger was to lie down on the floor or a mat or your bed at home and throw a tantrum by flailing your arms and legs while screaming. I participated in such workshops and exercises back then, and at the end of those sessions, I would be exhausted and feel embarrassed.

My mentor would tell me that embarrassment was not a feeling, but an intellectualization of feelings because embarrassment is a combination of hurt and anger, not a pure feeling taken care of as it occurred. He asserted that the body can handle only one feeling at a time, and if that feeling is not expressed with the body immediately then it goes directly to the mind where it is mulled over and sent back into the body for storage. He also maintained that the storage of these unexpressed feelings is what causes human beings to become sick and crazy, causes us to slouch our shoulders or stiffen our spines or lock ourselves up in the pelvis, tilting forward or backward out of alignment.

He was a language behavioralist, and his students studied until they could differentiate between sensing, imagining, feeling, wanting, and not want- 
ing. His students learned the language of feelings - how to say I hurt, I'm angry, I feel disgust, I feel joy, I am sad-and how these feelings had different degrees of intensity, from mild irritation, for example, to white cold rage. I comprehend, now, that my embarrassment was just as he said-an intellectualization of feelings. When I took those workshops, I thought I was feeling; I took his courses over and over, earning, finally, thirty semester hours in a course called Practicum in Language Behavior. Prospective employers have been known to give considerable pause when viewing this part of my undergraduate transcript.

Who knows where any of it starts? There are beliefs. There are religions. There are theories. There are parents. Then, there are those delicate seconds when the cell divides. There are the intricacies of chromosomes. There are the miracles and mysteries of the brain.

Maybe some synapses in my brain have always been frayed or missing, so that I never got the joke of why the chicken crossed the road, or the jokes my father told, such as NAACP stands for Niggers Ain't Actin' Like Colored People. My father was an American hero. I was the colonel's daughter in my white floor-length formal going through the reception line, shaking hands with the generals and their wives, wanting desperately to say something like good evening, turds.

But in my family, that sort of talking was forbidden, as was that sort of thinking. And, of course, all feelings were prohibited. We were emotional contortionists - if sad, we bucked up under it; if bored or bewildered, we put our noses to the grindstone; if hurt, we would grin and bear it; if depressed, we pulled ourselves up by our own bootstraps; if angry, well, we didn't get angry; if joyful, well, we didn't get that either.

When I was thirteen, I took my first diet pill. My mother gave it to me. It was dexedrine. I was gone, instantly. The reason she gave me pills is that she had a problem with my body, only I didn't know that was the reason back then. I thought I was too fat because she said I was too fat, and I lived in such an odd isolation that I had no other sources to check with. I can remember looking into mirrors and wondering what there was about me that was so fat, and I looked into those mirrors long enough and hard enough, with my mother's voice in the background, so that I finally became convinced that I was indeed fat-and ugly, too. 
The dexedrine, however, gave me a tremendous sense of power-so it didn't matter whether or not I was or was not fat. I thought that these diet pills made it possible for me to think. As my drug use progressed to include seconal, nembutal, and librium, I became more convinced of my ugliness, and I began thinking that the dexedrine only gave me the illusion of thinking - the downers were really thought. By the time I was eighteen, I was in a mental hospital. I got even more drugs then-thorazine and stelazine. And I didn't feel a thing.

Once, when I was out on a pass from the mental institution, my parents took me to the Air Force Academy. We visited Arnold Hall, where we stopped to admire the Hughes trophies my father had won for being the commander of the most outstanding fighter squadron in the world. We watched the cadets march off in formation to the dining hall. As we left the academy grounds that afternoon, my mother turned around to face me as I sat staring out the back window of the Oldsmobile. She said, "You could have had all this." What she meant was I could have married a cadet. That was the farthest thing from what I wanted. I wanted to stop hurting, wanted the pain to go away, the thing that felt big in my throat, the choking-I had no clue as to how to go about it. I didn't even know what it was. The other thing I wanted that day was to not have to clean the oven for her.

Well, the next day I did have to clean the oven. And scrub and wax the floor in the entire basement, on my hands and knees. No Cinderella metaphors intended. I was not out on pass from the state hospital so a messenger from the prince could come by with slippers. I was out on pass to clean the oven and the floors. My parents and brothers were getting ready to move to another state two thousand miles away. I, of course, would stay in the institution. I don't recall being angry about it. I do recall sitting at my mother's kitchen table and putting oven cleaner on the flesh of my left forearm. Then I sat there quietly as the cleaner ate a huge hole into me. When I couldn't stand the pain any longer, I rinsed my arm off under cold running water until I couldn't stand that any more. Then I finished cleaning the oven.

When my parents got home that evening from their dinner at the officer's club, I greeted them with shining floors, a gleaming oven, and my most spectacular second- and third-degree burn. Of course, I received medical 
attention at the local Air Force base dispensary. Then Dad drove me back to the state hospital where later I got a staph infection and am lucky not to have lost my arm altogether.

I never told anyone that I had burned myself deliberately, but rather passed it off as if I had just barely touched my arm to the side of the oven and had been burned instantly, such delicate skin, before I could dash to the sink to wash the stuff off. Also, if I had told anyone the truth about how the burn had come about, I'd have been dealt some more psychological mumbo-jumbo, maybe lost my Saturday night dance privileges on the ward. What I did was self-mutilation. Such acts are not regarded highly in mental institutions, especially if one mutilates oneself while out on pass.

In retrospect, I understand why I branded myself. It marked a passage. It meant that I would never clean my mother's spatterings again. It meant I would never bend again to scrub the black heel marks from my father's shoes off of any floor. It meant I was out of a job, the only job I'd ever known. It meant my family was leaving me in a mental institution.

I should mention now that in those days, I knew I wasn't right, somehow, but I knew that I wasn't crazy in the same way the folks around me were crazy. And I'm not just talking about other patients who were on the same wards I was on. I'm talking about everybody. Everybody I knew, anyhow. And I knew my parents, my brothers, my grandparents, aunts, uncles, and a few cousins. I knew my friends as closely as one can. I had many acquaintances and several teachers with whom I had brief contact. Without exception, I was a different kind of crazy. I was like that funny-looking pecan, culled from the rest of the nuts just after harvest.

The difficulties in me came, clearly, from the way I thought. I found it impossible to comprehend, for example, why my parents argued drunk in the middle of the night and then acted as if they had no middle-of-thenights, washing us children up and taking us to church, both of them so strangely rumpled looking, singing "The Old Rugged Cross," watching to make sure we put our quarters and dimes in the collection plate-the change they'd handed us in the car on the way-money I got to hold and almost have. It seemed that my whole life was like that-one instance after another of something I got to almost have. And I knew then, just as I know now, that almost is close-and close, after all, only counts in horseshoes, hand 
grenades, and skunks. The loneliest child in the world is the one the dog almost bites.

When I was two years old, we lived in Germany. I ran away from home every time I got the chance. I ran to the home of a German family who had children a little older than I was, a family who had a typewriter. The children were actually allowed to play with it. I would go there knowing my mother would take a branch off a bush in our yard and switch the backs of my chubby little legs for running off again. The switching was annoying, and I could count on it happening, but it didn't matter. What mattered was going to that other house and using the typewriter, even though I never wrote anything other than "pklmck dnh ieopdm" stuff. It was, to me, magic. The other writing I did at that time consisted of drawings I'd make on any blank space in my children's books - mainly figures of people and breasts, lots and lots of breasts. My mother was not amused.

In August of 1984, many years, pages, and drawings later, I entered a graduate writing program as a sober woman. I had no money. I asked my father if he would buy me a typewriter and let me make payments to him until it was paid off. At the time, he was retired from the Air Force and living in Florida in a beautiful home, complete with a swimming pool and fountain and grapefruit trees in the back yard. He couldn't help me, he said, because he was still paying the bill for my youngest brother's education-a bill, he said, that was more than fifty thousand dollars. When he told me no, I thought I would explode. I am not exaggerating. I felt the anger. I felt it from years of this sort of sexism. The education of my brothers was important. My education was some sort of scheme that wouldn't amount to anything.

I was told this sort of thing by many members of my family who thought my obsession with words was a nice little hobby, and inexpensive-how much can pencils cost? - but that I needed to study something, if I was determined to study, that would help me get a job doing something I was suited for, such as taking care of children, you know, in a day care center, or working with the elderly in a nursing home, or sitting with the dying in a hospital-families pay good money to people who will do that sort of thing - on and on, while I was banging out poems on borrowed machines and putting them on car windshields, holding them there with the wiper blades. 
See, it doesn't matter what sorts of things are happening on the freedom front or which women are winning Nobel Prizes if you're living with lunatics who think art is something other, something disgusting, something so frivolous that it need not even be considered, especially by women or girls. I'm angry that my family didn't encourage me, and for years I've beat this horse, expecting some sort of miracle, a whinny and a snort and a fine ride on the beach. I suppose I want that horse to sing some Dylan, sing "she's got everything she needs, she's an artist, she don't look back. She can take the dark out of the nighttime and paint the daytime black."

But the horse is dead. I suppose I'll be singing a song about how it's so lonely in the saddle since my horse died. Or how it's not. But I'll be singing. And I suppose that what I wanted to say here is how it's the singing that's important, surviving long enough to find your voice.

After locating the primary anger in my self-that I was unknown to and virtually abandoned by my own parents - I tried to trivialize that rage, saying that there are many more terrible things in life than that-millions of people who'd had it rough, millions of children who never made it out. For a while, I was convinced that I was a self-pitying whiney sniveler. But then a gesture or phrase from an anonymous someone, a certain tilt of someone's head or a glance of disapproval, the way afternoon sun came through a gauze curtain, a yowling alley cat-something would trigger me, send me time-travelling backwards to the racist, sexist, anti-common pile of shit I was born into-a place where there was no room for the beauty I have come to call life, no time for embracing all that is tender, no reason or need for wonder.

And I told myself I should be angry at all the other things I've endured out of ignorance-a husband who emptied a nine-shot automatic at my running-away back, a target he couldn't hit because he was too drunk to aim straight; a man who put a gun to my head, pulled the hammer back, then told me I wasn't worth a bullet; the molesting and offenses some of the esteemed male members of my family heaped upon my girl's body; my father's kisses; my mother's games. Those occurrences, God help us all, are in me somehow forever. Sometimes it's enough to have lived through it. It's when the creation of art is threatened that I become furious and begin writing lists with headings such as "Why I Don't Own a Gun." 
All those years of my early life, when I thought I was crazy, or when my mother thought I was crazy and told anyone who'd listen, all those years of an absolute abject poverty of spirit, there was in me a tiny, tiny thing that was soft and pure, that wanted nothing more than to sleep clean and sound and unafraid, a tiny thing that talked to me in a soothing way, that told me it will be all right, don't cry now, it's going to be okay, a tiny warm something that was inside me when I hugged myself because the tears were not stopping and I had no words to say for the sorrow of my heart. That small thing is somehow the adult I am growing into-that grown woman who comforts, having comforted herself all those other years, that woman who is finding the words.

Today I worked for a while on a jigsaw puzzle-one of those with lots of blue and green that reduces me to sorting puzzle pieces into shape categories, then trying each piece in one category in an appropriately shaped space-maybe only puzzle folks will understand what I'm trying to say. Anyhow, when this puzzle is completed, I'll laminate it with some of that puzzle glue and hang it on the wall. Then I'll go buy a new puzzle and go through the motions again. I find puzzles help because of the concentration they demand. Back in my state hospital days, we had only one puzzle on our ward. We put it together over and over and over. When we wanted variety-a challenge-we would put it together gray side up. The past. What a hoot.

It is because of my experiences as a human being on this planet that my interests have always been sanity and language. It doesn't surprise me that my undergraduate degree is a double major: Mental Health and English. I went on to graduate study in Guidance and Counseling, dropping out of that program six hours short of a degree when one of my counseling program professors wrote on a paper of mine that my writing was so entertaining that he was certain it was a defense mechanism and that it would behoove me to "quit horsing around." My mother had used that word toward me when I was little-behoove-and I thought it meant to cut the feet off horses. "It might behoove you to clean your room."

It may be ironic that when I was first admitted to a mental hospital at eighteen, I was diagnosed, in part, on the basis of what I'd written in diaries and in a suicide note-these writings given by my mother to the psychiatrist at his coercion because I wouldn't talk to him. I would go into his office, 
stare at my bandaged wrists, and cry. I thought he was profoundly weird. He moved too quickly and tapped his pen on his shoe sole, his right foot resting on top of his left knee, his office walls boasting horse heads - painted well and framed-and horse figurines, some ceramic, some bronze, some stopped cold in brass. He acted impatient with me, increased my medication, and sent me to occupational therapy where I laced a wallet. When the ward nurse found the diary I'd written while on the ward that included notes about the smell of the place, the food, the doctor-notes that were not kind, but true-she gave them to the doctor. I lost television privileges and got some more librium. But it didn't stop me. Pretty soon, I was running an underground writing coalition with the other patients.

The hospital I was first in was a private one and the primary treatment was electroshock therapy. We called it the fry. The electroshock caused horrible memory problems. So we made lists of things we didn't want to forget. I wrote those lists. After the initial six-hour recovery, I'd get whoever's list and we'd read it over and over so we could get ourselves back a little. I taped these lists to my feet, putting a finger inside my sock from time to time as if scratching my ankle or arch, feeling for a corner of paper so I'd know we were safe. Socks were the only thing they didn't take off of you for the shock-rack, the table with the straps. Sometimes they'd give some pentathol before the jolt. Sometimes not.

Another interesting thing occurred when I entered a treatment center at age forty. (I want to mention that my early hospitalizations - three months in a private hospital and a year in a state hospital - taught me how to stay out of mental hospitals as a patient. I became an employee.) I took with me to treatment a carton of cigarettes, a purple chenille robe, three poems, and my expired driver's license. When the treatment staff read the poems, they decided to contact an English professor at a local college so that he could help them discern if I was a member of a Devil Cult. The professor told them not to worry, that I was just a writer.

The reason I know this story is that one of the staff members told me. She liked to remind me about my first days of sobriety, how I marched up to her desk, in between delirium tremens, and demanded I be allowed to write in pen because I was a writer, telling her that pencils were for people who weren't on purpose. She told me I would use a pencil just like everyone else, because in the next few days I'd need to erase a lot. 
All of us in treatment had to write our drug and alcohol history before we could be transferred out of detox. And everybody wanted out of detox because we wanted our clothes back. You had to wear hospital gowns in detox, but you also had to go places, such as the cafeteria, and sit in the breeze. I wrote in pencil. I erased. I wrote in pencil some more. It took me nine days to write my history of alcohol and drug use. After revising, it was one sentence: "My name is Judy, and I'm an alcoholic." My notes for that sentence were fifty pages long. But I was new. And since that day, I have been present and able to attend to my continuous newness. I am the parents of this creation. I am the one who loves me.

My friend and I graduated from the writing program, both of us earning degrees in creative writing. We visit each other a couple times a year. She practices Siddha Yoga these days and says it helps with the rage. We both know that part of the impotency of our anger is historical in naturewomen are expected to be a little crazed, it's hormonal, etc. - and that part of it is that we really don't know what to do with anger, so we polish the toaster or busy ourselves with cloth, we take walks that get longer and longer, we keep bees. And we make art.

Many of us make in-between art, and I don't mean an art that is less-than. I mean art that is sandwiched in between everything else in those few moments we must make for ourselves. Sometimes there is irritation at being called away from a poem or painting or piano or bowl or song, but there is also a reverence for those call-aways. After all, we get our voices and hone them, we compose from our experiences, our call-aways. We are on hold, sort of, on both sides.

These days, I live in the country - a village with a population of 114 . I feel my feelings - all of them-and seldom do they get saved in my body for longer than a day. I'm still learning. I keep a very low profile. Now, it's enough to live and write. I have a garden in the summer-tomatoes, peppers, beans, melons, and potatoes. As I've been working on this writing, the female white German Shepherd has given birth to eleven puppies in the bathroom closet. The second pup to come was stillborn and is buried in the yard. The other ten will open their eyes soon. I can hardly wait for them to see the world.

My neighbor to the southwest has beautiful horses, white ones. Some mornings I watch them from our back porch and they look like ghost 
horses when the fog's just right. I say these could be the horses of the Apocalypse. I say I've got a good seat for the show.

\section{OUt IN THE MiddLe of SOMEWhere}

I'd like to say I don't know how I got here, but that would be a lie. I broke the law. I got caught. I'm here. This is the law I broke: "Love humanity, but do not love any particular human." It's one of my own laws. Humans do that, make up laws for themselves - rules to live by. Such as never eat anything with mayonnaise in it at a restaurant. That was one of my mother's rules. If I could trace that rule to its origins, maybe I'd discover that at some point in history a person had become ill after eating a tuna salad sandwich in a café. Maybe the person died from the illness. Maybe it was even caused by the tuna salad. And the story caught on-poor old Henry ate that sandwich and folded out in the street . . . it was the mayonnaise . . . it can kill you if they don't keep it cold. Like that.

The reason I made up the law about loving humanity but not any one human in particular is that people are such jerks. There's something almost endearing about billions of bozotrons on one planet, something distantly dangerous in the infinite possibilities a billion egos can create, whereas there's a more immediate danger when you're real and you're in a room with just one lunatic other than yourself.

And I'm not talking about the lunatics who murder their children, although I've known two women who did just that; and I'm not talking about the crazed teenager who takes an ax to her mother in the cellar, although I've known one girl who did exactly that; and I'm not talking about having Easter dinner in the same house with a couple who are already having trouble and by Halloween he will put five bullets into her at pointblank range until she quits crawling away from him and dies on her living room rug, but I knew them too.

Just today I came out of a restaurant in a small town in the cold rain and saw a man in thermal wear carrying deer antlers that were so fresh that the blood was still red and wet on the skull-between. At the curb was a pick-up truck with an entire dead deer in it. Three men were standing at the tailgate. 
One of them said something and laughed and slapped the dead deer's front shoulder as if they were pals of some sort.

When I was eight, I killed a snake. At least I think I did. I don't remember doing the actual killing. I remember the snake was dead. I remember remorse, and that I had an elaborate funeral for the snake, complete with a shoebox casket and a grave. I read from the Bible. I think the snake was in pieces. Everything is a no-win situation when you're eight and the snake is dead, a situation that only gains in speed and gravity as you begin to understand words such as Creature. Create. Creation.

I mean, pretty soon, if you're lucky, you'll be fifty and still promising yourself fire, casting off on the way all things of diminishment so that you may-at last-sit down some morning in sunlight and write all those notes you've been composing in your head for years, starting with the ones of love for a change because there's just not enough time, even if you live another fifty years, to file those formal complaints about how the biscuits at Hardee's just aren't as good today as they were ten years ago. And when it comes to biscuits, I know what I'm talking about. I'm talking about people, like me.

I'm sure it would all have turned out a lot differently if I hadn't spent five years of my life trying to pass myself off as a lesbian. And now I've got to deal with all the consequences of that. It's a fact that it was not love for women that took me to their beds, but simply the desire to be the best lover any of them had ever had. And then to let them crave me. From afar, since I'd be long gone by dawn, even if the dawn was a year in arriving. But love? Not hardly. Certainly there was some swooning around in the gentle forbidden. There was an odd pride in being a part of the "alternative" lifestyle - a pride that felt almost like power. There was also a voice in my head that would, from time to time, say quiet things to me, such as, "This is fucking crazy." And although what the voice in my head said is a twentieth century idiom, it became-for me-an absolute. I stress the "for me" because I do not presume the consciousness or the correctness, politically or otherwise, of any other person.

I told one of my friends about my lesbianism, and he wrote me a long letter about how he thought it was a shame that I'd gotten all svelte for girls. In what I thought was an attempt to accept my decision, he ended his letter by writing, "It doesn't really matter. Fucking is fucking." I want to call attention to the fact that lesbianism was a decision for me-a conscious 
decision. It may not be so with other women. And my friend was wrong. It does matter.

I'm trying to tell the story of how I came to love a man, a man I met while professing to be a lesbian, and how I came to live in a small hovel in extremely rural Missouri with him. But trying to tell this story is like trying to get my mind around some philosophy of life that is larger and lighter and darker than life is, a philosophy that is both dense and filament, the train and the dream of it. Part of the problem is motherhood. I suppose I need to identify the problem now since I've written the word motherhood. I wanted to write "part of the problem is my mother." In fact, that's what I wrote and then changed because of one of those minor epiphanies that occurs when I am certain I've just written the unmitigated truth, but then a can of paint hits me in the head, just like in the movies, swinging from a rope.

So. My mother, let me be the first to extend my round, middle-aged woman's body to her after a two-hour ride through Florida in mid-July in an old Chevrolet in which the air conditioner no longer works, during which time I smoked at least ten cigarettes. Let me arrive with a sweatsoaked blouse to the front door of her new house, let her show me around, the new car they got yesterday, let me take photographs of her and her new husband, let her sit me down in her kitchen where there's a huge chocolate cake on a plate under a glass dome. Let me be cooling off from the hot ride there, let me be thirsty, let her husband come from his office into her kitchen and get himself a refill from the cold bottled water, let him say something about the road construction, the miles and miles of it to get to where they live, let me hear myself talking about the heat and how we made the ride with the windows down, let my mother tell her four-sixty air conditioning joke-four windows down, sixty miles an hour, let her bring me up to date, let me be stubborn or stupified or bewildered, let me just see my mother's face, not this face, let me not have to ask for water, oh please, please see me and give me water, cake.

That's close to how it went. She didn't offer me anything to eat or drink, not even a glass of water; and I didn't ask for anything, not even a glass of water. I've left out pages of conversation, but it was the same conversation we have had for at least thirty years and is actually a play I'm writing called Tickle Tokie. I've named it that to commemorate a childhood game my mother taught me, a game I played with her, a game I went on to play with others, a game I got in trouble for playing without her. "Tickle Tokie" is 
what my mother called masturbation. Her name for it is actually more musical. Maybe it doesn't make a difference what it's called. I mean, the drum in the head keeps the beat regardless. Anyhow, it was in her kitchen that the memory came back as clear and cold as the bottled water her husband poured, scenes from under or beyond the bourne of consciousness. I kept an empty, smiling countenance even though I felt as if my face was sliding off onto her floor.

Here comes that can of paint: all of this is from my point of view. What about how she saw it? What story did she tell her friends, her husband? After all, we had not seen each other in ten years and I call her from Orlando and say I'm in the neighborhood, that I'd like to take her out for lunch and she says come over, but she can't go out to lunch because she's in too much pain. Then I show up all hot and sweaty and big-breasted and blonde, the sort of woman she can't stand anyhow. There I go again with my point of view. She talked about being vain, about not wanting to have to use a cane. I told her she could get a designer cane, maybe something diva-like with jewels. She said she wanted one with a button she could press and a stiletto would come out the end. She was joking. And I suppose therein lies the rub. Our humors.

What this has to do with this man I live with and love gets complicated here, or maybe not. Maybe this is where it gets figured out. His mother loves him, and she is the sort of woman who either knows love instinctively or has learned it so well and deep that it seems instinctive. She knows that it is most important to keep the rituals of common living out in front with her family - on Thanksgiving, there will be turkey with all the trimmings and pie and cake; at Christmas, the tree will be a living one to plant in the yard later, the gifts will be ready for the children, Santa will come with bicycles and doll houses, and everyone will eat too much homemade candy; for Easter, we'll blow the egg part out of the duck eggs and paint the shells with beautiful enamel colors; there will be birthday parties for every birthday of every child, with a big cake and candles and lots of presents. And to hell with the rest of it, the rest of it being what the neighbors might think or what anyone in the world might think, and to hell with thinking. We've got to go pick up a trampoline for the side yard. There will be time for thinking later. Right now, we've got things to do.

And the man I love also loves his mother. He is the sort of man who will go on vacation and buy jewelry for all his women relatives back home-and 
he'll buy that jewelry from a woman at a rest stop in Arizona, a woman who has displayed her work on a blanket she's spread out on the concrete. He's the sort of man who has made a tampon run on behalf of his niece during an ice storm. He's a man who knows how to love and does it so completely I could just cry. He's the man my mother never told me about.

But that's not the problem. The problem is that this past summer we bought a computer and went on-line. That's not really the problem. Here's the real problem: The man I love and live with has begun to explore his attraction to men. This past summer, I watched as he fell in \& out of love with someone else. He tells me he loves me, and I believe him. I guess that's not the problem. I guess the problem is me. I don't like the way I feel. I have cried until there is no real way of thinking about any of this and water just comes out of my face. The hurt doesn't even stop in my chest to make an ache anymore-it goes directly to the middle of my brain and says perfectly clearly, "This is fucking crazy."

I would like to blame everything else. I would like to blame the men who sexualized him when he was a child, the ones who abandoned him after zipping their pants, just like I'd like to blame my mother's beautiful woman's body and the way she taught me to touch her, myself. I'd like to line up all the people who ever sexualized anyone, who ever involved another human being in any sexual act that did not have its origins in the sanctity of love-line them all up and rip out their hearts. But that would mean I'd have to rip out my own heart, and God knows how many other hearts - a job of monumental proportions, one requiring more time and hatred and guts than I've got.

Sometimes I wish I didn't know about his childhood. Sometimes I wish I didn't know about my own. I cannot suppose that his early experiences have anything to do with his adult self, other than serving him with memories. I cannot say, "Well, obviously he was environmentally imprinted." I can think it is a possibility that his post-birth history has created him, just as I can think he was born into this world with a certain genetic code that rules. I have barely begun to find answers about my own self. It was not easy to go to him with the news that I know I am a flaming heterosexual. It was not easy to look at myself and all the entanglements I've had. It's not easy to admit that all I want is to be with this man who loves me in all the ways a man loves a woman. And the hardest part is knowing, all the way to the bone, that I cannot fulfill all his longings. I can 
suffice in the part of his life that needs to be spent with a woman. The part of him that needs what he finds with a man is so far from me that it's like I'm on Mars, and yet so close that I breathe its air. I know this much: he is a much happier person than he was before he began this part of his journey. Maybe happier isn't the right word. He's more alive. He's not lost anymore. He's closer to everything. It's as if he knows the way home.

At first, when he began to seek the company of men, I was furious. Not with him, but with the fact that I didn't have a penis and wasn't a man. It seemed like the cruelest of cosmic jokes. And it was not a new joke. When I was a tiny child, I prayed every night. All I asked God for were breasts like my mother's and a penis like my father's. I actually believed that God could bestow such attributes. I don't know if my prayer was the result of being sexualized by both my parents or if such a prayer is common in tiny children. All I know is that I prayed it. And that it was the prayer of a child.

The man I live with and love thinks I am in denial. He has described me to his friends as his lesbian roommate. It used to bother me that he did that. Call it label sensitive. But it doesn't matter today. I am exceedingly glad to be who I am, to know myself as I do, to welcome what this day brings. Each day gives me time to get ready for whatever happens next. I have matters of the spirit to attend to. I have quietness to acquaint myself with. I have silence. I am still. These are the prayers of a woman.

I got here via obsession, but I stay here because I love. What I have here is his excellent company, someone who wants to know where I am and what I'm fixing for dinner, someone with whom I will gladly assume any position, a man I have loved since the day I met him, a human being who is simply the best person I have ever known, who will make me promise not to go crazy while he is gone this time, who will always promise to come back and who will come back, who doesn't want to come home to a note on the table, a note he will recognize at once as the one he will have to hunt me down over, hunt me down and spit on me for writing, the only note that I can't write from this place, this place where love only means one thing. 